\title{
Potential of climate-smart agriculture in reducing women farmers' drudgery in high climatic risk areas
}

\author{
Arun Khatri-Chhetri ${ }^{1}$ (D) Punya Prasad Regmi ${ }^{2} \cdot$ Nitya Chanana $^{1} \cdot$ \\ Pramod K. Aggarwal ${ }^{1}$
}

Received: 6 September 2017 / Accepted: 13 December 2018 / Published online: 17 January 2019

(C) The Author(s) 2019

\begin{abstract}
Climate-smart agriculture (CSA) has a significant role to play in reducing the gender gap in labor burden for women in agriculture. A targeted approach to address this gap can be useful in developing a women-responsive climatic risk management plan focused on reducing their labor burden in agriculture, especially in areas with high climate risks. The paper therefore presents a top-down approach to identify potential labor-saving CSA technologies for women farmers in areas facing high climate risks. It involves mapping women in agriculture, climate risks, and poverty hotspots and entails understanding the role of women in agricultural activities to identify the suitable CSA options for reducing the levels of labor drudgery. The study is illustrated for Nepal where feminization of agriculture is rapidly increasing, a high level of climatic risks persists, and adaptive capacity to climate change is very low, especially among women in agriculture. Results are presented for two hotspot districts, Rupandehi and Chitwan. Household socioeconomic characteristics were found to play a major role in women's labor contribution in different crop production activities. Discussions with farmers provided a list of more than $15 \mathrm{CSA}$ interventions with labor reduction as well as yield-improving potential. Accordingly, considering the local crop, agro-climate, and social conditions, and women's participation in different agricultural activities, CSA technologies and practices such as direct seeded rice (zero tillage and low tillage using machine), green manuring (GM), laser land leveling (LLL), and system of rice intensification (SRI) were found to potentially reduce women's drudgery in agriculture along with improvement in productivity and farm income.
\end{abstract}

This article is part of a Special Issue on "Gender Responsive Climate Smart Agriculture: Framework, Approaches and Technologies" edited by Sophia Huyer and Samuel Tetteh Partey.

Arun Khatri-Chhetri

a.khatri-chhetri@cgiar.org

1 CGIAR Research Program on Climate Change, Agriculture and Food Secuirty (CCAFS), International Maize and Wheat Improvement Center (CIMMYT), New Delhi, India

2 Nepal Development Research Institute (NDRI), Kathmandu, Nepal 


\section{Introduction}

Women's involvement in agriculture and their contributions to food security has been widely recognized in the developing countries. Women play a key role in improving agricultural productivity and food security in the farming communities (Agarwal 2013; Aly and Shields 2010). In the last few decades, women's involvement, access to productive resources, and decision-making roles in agriculture and allied sectors have been the focus areas of research and development in the global south. Many studies claim that differences in men and women's responsibilities, priorities, and access to resources and services at the community and household levels are responsible for the gender gap in agriculture in many developing countries (Quisumbing et al. 2014; FAO 2011). A clear linkage has been shown among social, economic, and gender dimensions in agriculture (Peterman et al. 2014; FAO 2010a).

Agriculture is one of the most vulnerable sectors to climate change impacts. Within agriculture, however, several studies highlight that women are likely to be affected more than men by climate impacts, especially in the developing countries where their involvement in agriculture is high (Goldsmith et al. 2013; MacGregor 2010; UNDP 2013; Goh 2012; Nellemann et al. 2011). Most of this gender gap analysis in agriculture in the context of climate change have been limited to access to resources and decision making (Kristjanson et al. 2017). However, the labor-intensive roles that women play in agriculture from sowing, weeding, to harvesting also determine the nature and severity of climate change impacts they face. Climate change impacts such as decreasing supply of crop residues and biomass for energy and livestock feed, increasing severity of weeds, crop resowing/transplanting requirement, and loss of crop yields are likely to affect women more, given their involvement in related activities (Bradshaw and Linneker 2017; Nelson and Huyer 2016). Thus, there is a need to understand climate change impacts on women based not just on their social, cultural, and economic characteristics but also their role and responsibilities in specific agricultural activities (Nightingale 2011; Morton 2007).

The climate-smart agriculture (CSA) approach is emerging as a new paradigm for adapting agriculture to the changing climate. This approach seeks solutions that improve agricultural productivity, build resilient food production systems, and reduce greenhouse gas emissions (FAO 2010b; Steenwerth et al. 2014). CSA includes a range of technologies, practices, and services to minimize the impact of climate change in agriculture. These CSA options range from a simple adjustment in crop management practices to the transformation of agricultural production systems to adjust to new climatic conditions in a particular location (Khatri-Chhetri et al. 2017; Vermeulen et al. 2012; Howden et al. 2007).

However, the efficacy of CSA options in terms of its benefits to both men and women stands to lose out if the gender gap in agriculture is not taken into account. (Nelson and Huyer 2016). For instance, the level of women's involvement in agriculture, such as their labor contribution in different agricultural activities (from land preparation to crop harvesting), can have significant implications for the adoption and sustainability of the CSA approach. There are plenty of suggestions for gender-differentiated climate change adaptation strategies in agriculture. Improving women's access to productive resources, finance and knowledge, promoting off-farm employment, and capacity building on adaptation options can empower them to adapt to a changing climate (Huyer et al. 2015; Edmunds et al. 2013; Chaudhury et al. 2012; Huyer 2016). While the role of CSA in agriculture has been widely discussed, its potential to help women in reducing their labor burdens in particular is not clear.

This paper therefore presents a systematic approach to assess the labor-reducing potential of selected CSA technologies and practices. The objective is to highlight hotspots of women in 
agriculture, climate risks, and poverty; assess CSA interventions relevant for women in two of these hotspots, based on their role in agriculture and factors affecting the role; and evaluate some of the CSA technologies on their labor-reducing potential for women in agriculture. The study was conducted in Nepal, a country characterized by low-ranked gender-related development indicators and increasing feminization of agriculture due to male out-migration (UNDP 2016; CBS 2013a; Gartaula et al. 2010; Tamang et al. 2014).

\section{Methods and data}

\subsection{Identification of hotspots}

Three indicators were used to map women in agriculture-poverty-climate risks hotspots across Nepal. The first indicator was women's involvement in agriculture which was calculated as the percentage of women in agriculture in the district multiplied by a weight. The weight was the proportion of total number of women involved in agriculture in the district compared to that of the country. Data for this indicator was collected from the national population and housing census survey in 2011. Participation in agriculture also included forestry and fishing industries. The second indicator was climate risk exposure at the district level developed by the Ministry of Environment, Government of Nepal. This exposure indicator included annual temperature and rainfall trends, droughts, floods and landslide risks, and population dependency in natural resources and other risks factors (GoN 2010). The third indicator was the district level poverty ( $\%$ of population under poverty line). The poverty levels were taken from the census data, which was conducted by the Government of Nepal in 2013 (CBS 2013b).

The hotspots were identified by overlaying women's participation in agriculture with climate risk exposure and poverty levels using a GIS (geographic information system) tool. Since the study focused on women's participation in agriculture, $50 \%$ weight was given to this indicator while a weight of $25 \%$ was given to each of the other two indicators. All three indicators - women's participation in agriculture, climatic risks and poverty level—were combined and normalized between 0 and 1 values. Using the "Jenks Natural break" method in GIS, the district values (combining women's participation in agriculture, climate exposure, and poverty) were categorized as low (below 0.4), medium (0.4 0.65 ), and high (more than 0.65). Districts under the "high" category were defined as the hotspots, where both the women's participation and the climate risks and poverty were categorized as high.

\subsection{Assessment of women's role in agriculture}

Two women-agriculture-climate change vulnerability hotspot districts (Rupandehi and Chitwan) were randomly selected for a more detailed assessment. Gender disaggregated data on labor contribution was collected from a cross-section survey of randomly selected 215 agricultural households in 2013/2014. Quantitative data was collected using a questionnaire on men and women's role in different agricultural activities such as land preparation, crop sowing, tillage, weeding, harvesting, and threshing in major crops. Participation has been measured in terms of labor days contributed to particular agricultural activity.

To compare men and women's participation in agricultural activities, we compared the average labor contribution to each agricultural activity from land preparation to crop harvesting using mean comparison test ( $t$ test). Additionally, to understand variables affecting women's participating in agriculture, a multiple regression model was run using total labor 
contribution by women in different agricultural activities (dependent variable) and independent variables such as landholding size, family size, main occupation of household head, gender of household head, and non-agricultural income.

\subsection{Potential benefits of CSA options for women}

To identify a list of currently adopted and potential CSA technologies for the study areas, focus group discussions were conducted with five women farmers' groups in each research location. In addition, a review of CSA-related literature was also conducted. The technologies were identified based on the dominant crops in these regions (MoAD 2015) (Table 1). The group participants were also asked about the potential impact of the identified CSA technologies on labor, income, and yield.

The study used five major indicators including gender to assess the potential benefits of CSA options in the study areas (Table 2). For each technology and indicator (except environment), primary data was used for calculation of an index (details in Annex 1). Secondary information was used to calculate the environment index using a study from Pathak and Aggarwal (2012) about low carbon technologies for agriculture. All CSA technologies were evaluated by comparing with and without technology intervention scenarios by using an index where the value for farmers' conventional practice (FP) is 100. For the objective of this paper, we have mainly focused on the gender indicator which highlights the change in women's involvement in agricultural activities due to the introduction of CSA technologies and practices. Technologies which reduce women's labor contribution including improvement in productivity and income have been considered as women-friendly technologies. Given the focus on reduction in labor burden, this study did not consider other outcomes of CSA such as changes in women's decision-making authority, changes in women's control over income, and improved access to agricultural resources. Out of the list in Table 1, we estimated a gender participation index for six prominent CSA technologies adopted in the study areas. These technologies include direct seeded rice without machine use and with machine use, system of rice intensification, zero tillage and direct seed rice, green manuring, and laser land leveling.

Table 1 Technology adoption for three major crops in the study areas

\begin{tabular}{|c|c|c|c|c|}
\hline District & Rice & & Maize & Wheat \\
\hline Chitwan & $\begin{array}{l}\gg \text { Direct seeded rice using } \\
\text { machine } \\
\gg \text { Zero-till DSR using } \\
\text { machine } \\
\gg \text { Organic rice production }\end{array}$ & $\begin{array}{l}\gg \text { Laser land leveling } \\
\gg \text { Agro advisory services }\end{array}$ & $\begin{array}{l}\gg \text { Zero-tillage } \\
\text { maize }\end{array}$ & $\begin{array}{c}\gg \text { Zero-tillage } \\
\text { wheat } \\
\gg \text { Power tiller } \\
\text { seed drill } \\
\gg \text { Surface } \\
\text { seeding }\end{array}$ \\
\hline Rupandehi & $\begin{array}{l}\gg \text { Direct seeded rice using } \\
\text { machine } \\
\gg \text { Direct seeded rice hand } \\
\text { broadcasted } \\
\gg \text { Direct seeded rice } \\
\text { zero-till plot } \\
\gg \text { Green manure rice } \\
\gg \text { SRI }\end{array}$ & $\begin{aligned} \gg & \text { Crop insurance } \\
\gg & \text { Laser land leveling } \\
\gg & \text { Submergence tolerance Variety } \\
& \quad(\text { Swarna Sub-1) } \\
\gg & \text { Agro advisory services }\end{aligned}$ & & $\begin{array}{c}\gg \text { Zero-tillage } \\
\text { wheat } \\
\gg \text { Power tiller } \\
\text { seed Drill } \\
\gg \text { Surface } \\
\text { seeding }\end{array}$ \\
\hline
\end{tabular}


Table 2 Main indicators and sub-indicators used for CSA technology evaluation

\begin{tabular}{ll}
\hline Indicator & Proxy indicators \\
\hline Efficiency & - Productivity \\
& $\bullet$ Unit cost of production \\
& $\bullet$ Gross margin \\
& $\bullet$ Benefit-cost ratio \\
Equity & - Profits \\
Gender & - Employment generation \\
Sustainability of natural resources & - Additional calorie produced \\
& $\bullet$ Women participation \\
Environmental & $\bullet$ Nitrogen use efficiency \\
& $\bullet$ Water use efficiency \\
& $\bullet$ Energy use efficiency \\
\end{tabular}

\section{Results and discussion}

\subsection{Women in agriculture-poverty-climate risk hotspots}

Figure 1 presents hotspots of women in agriculture-poverty and climate risk across Nepal. Twenty-one districts are identified as "hotspots." Since 2001, the out-migration of economically active male labor from the hotspot districts is relatively high compared to districts falling under the "low" category (GoN 2014). Consequently, women's participation in agricultural activities in the hilly regions has gradually increased in the recent decade (MoLE 2015). Incidence of drought and floods, changes in rainfall patterns and population dependency on the use of natural resources such as forest and water are also high in the hotspots (NEOC 2015). These districts, therefore, become important areas for prioritizing efforts to promote womenfriendly CSA interventions.

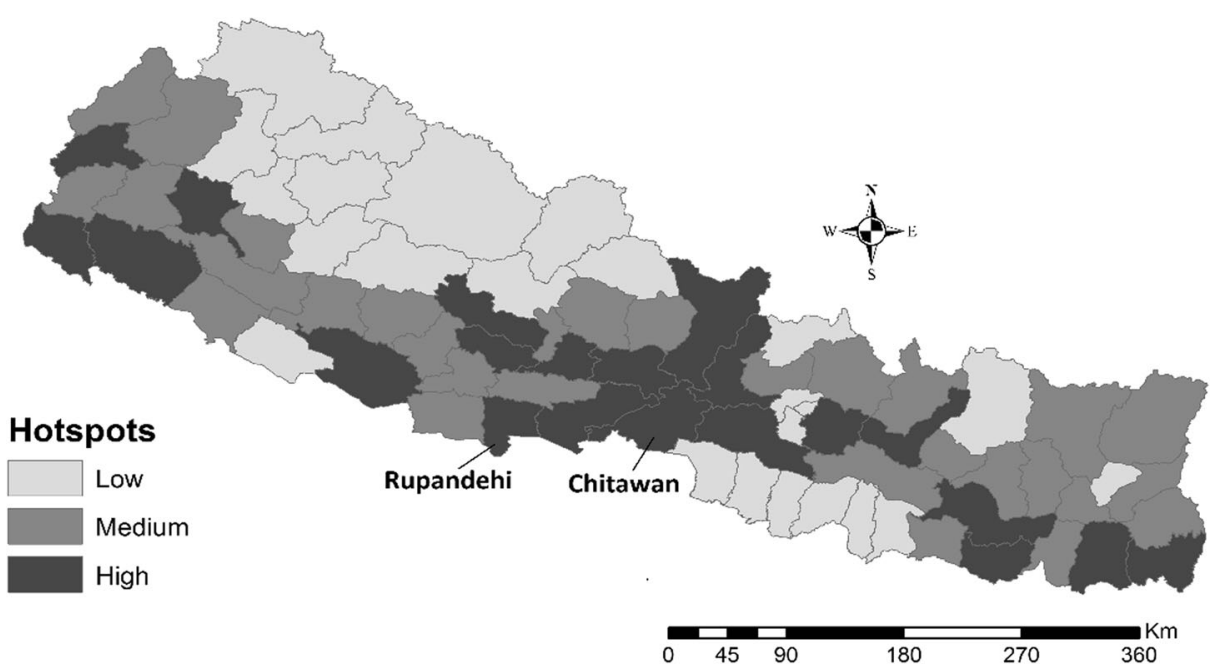

Fig. 1 Women-agriculture-climate risk hotspots in Nepal 


\subsection{Climatic risks and impacts in study areas}

We selected Rupandehi and Chitwan districts from the hotspots for a detailed analysis of women in agriculture and climatic risks (Fig. 1). Survey results identified flood, extreme and erratic rainfall, cold waves, and frequent droughts as the major climate change events occurring since 2001 in these areas. Many farmers reported significant crop yield losses (30-70\% loss) as a result of these events. Incidence of climatic risks in these two districts, households affected by them, and their negative effects on crop production all increased from 2003 to 2012 (Fig. 2).

Similar to farmers' experience, the incidence and severity of climatic risks such as flood, droughts, rainfall-induced landslides, and thunderstorms have also increased in the last decade across Nepal (NEOC 2015; Krishnamurthy et al. 2013). Since 2007, the frequency of these extreme weather events has increased significantly, with their occurrence every alternative year. Figure 3 highlights the number of times these events happened across the country during 2000-2014.

\subsection{Labor gap assessment in agriculture}

Figure 4 presents the average days of labor contribution of women and men in the surveyed households. Women's labor contribution in agriculture is significantly high compared to men's contribution. The range of total number of days of women's labor contribution to agricultural activities among the survey household is also large. This high level of women's involvement in agricultural activities is largely influenced by out-migration of male and/or low off-farm opportunities for women. They work primarily as family workers in subsistence agriculture with low technology-driven conventional farming practices.

Table 3 clearly differentiated the role of men and women in agriculture. In some activities, such as rice transplanting, weeding, irrigation application in rice, and harvesting/threshing of wheat and maize, women' labor contributions are significantly high. Land preparation, crop

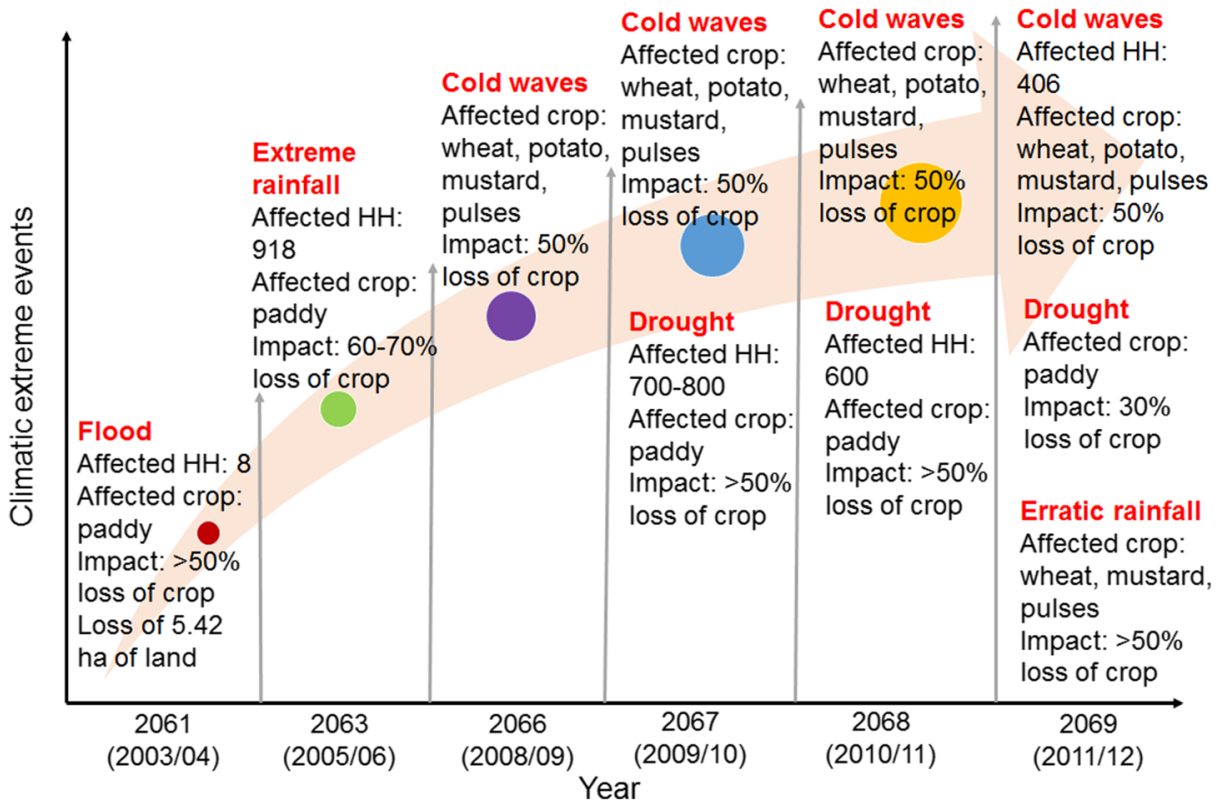

Fig. 2 Historical trend of climatic extremes events and impacts (source: Household Survey 2013/2014) 
$\rightarrow$ Flood $\rightarrow$-Severe Drought $\rightarrow$-Rainfall inducded Landslide $\quad-$ Thunderstrom

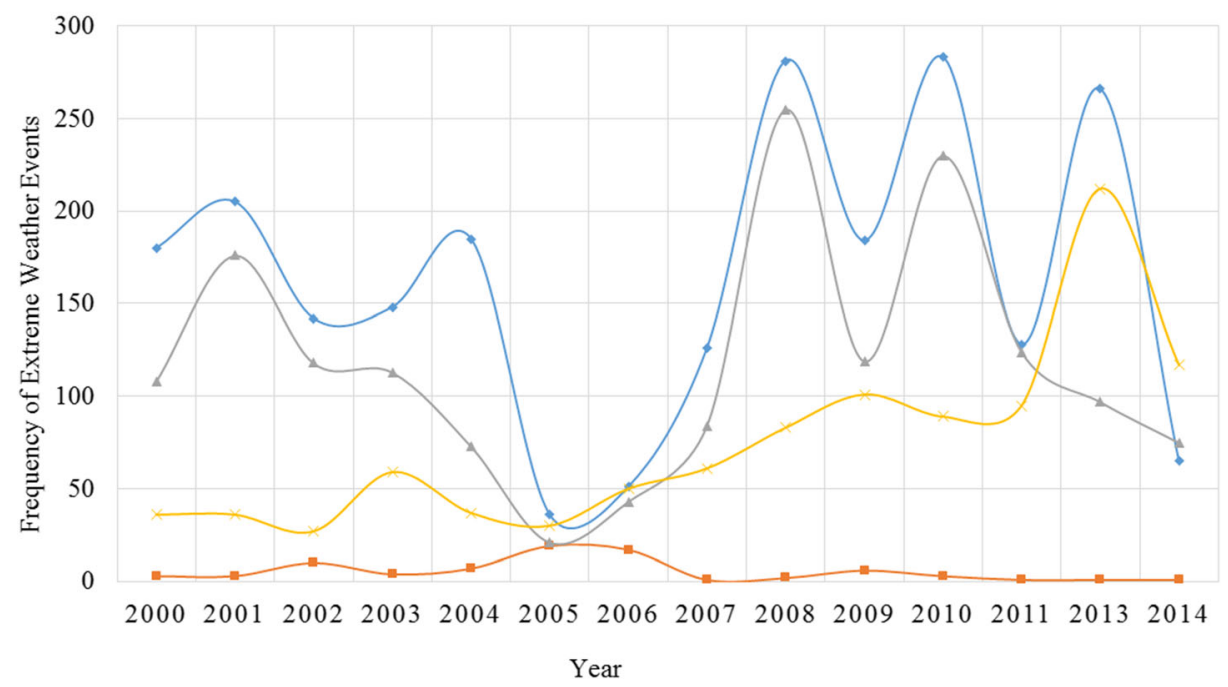

Fig. 3 Trend of extreme weather events in Nepal (source: National Emergency Operation Center)

sowing, and fertilizer application, on the other hand, are mainly men's responsibility. This information builds the case for the promotion of CSA technologies that, for instance, facilitate transplanting of rice, weeding, and harvesting/threshing which can significantly reduce women's labor contribution in agriculture.

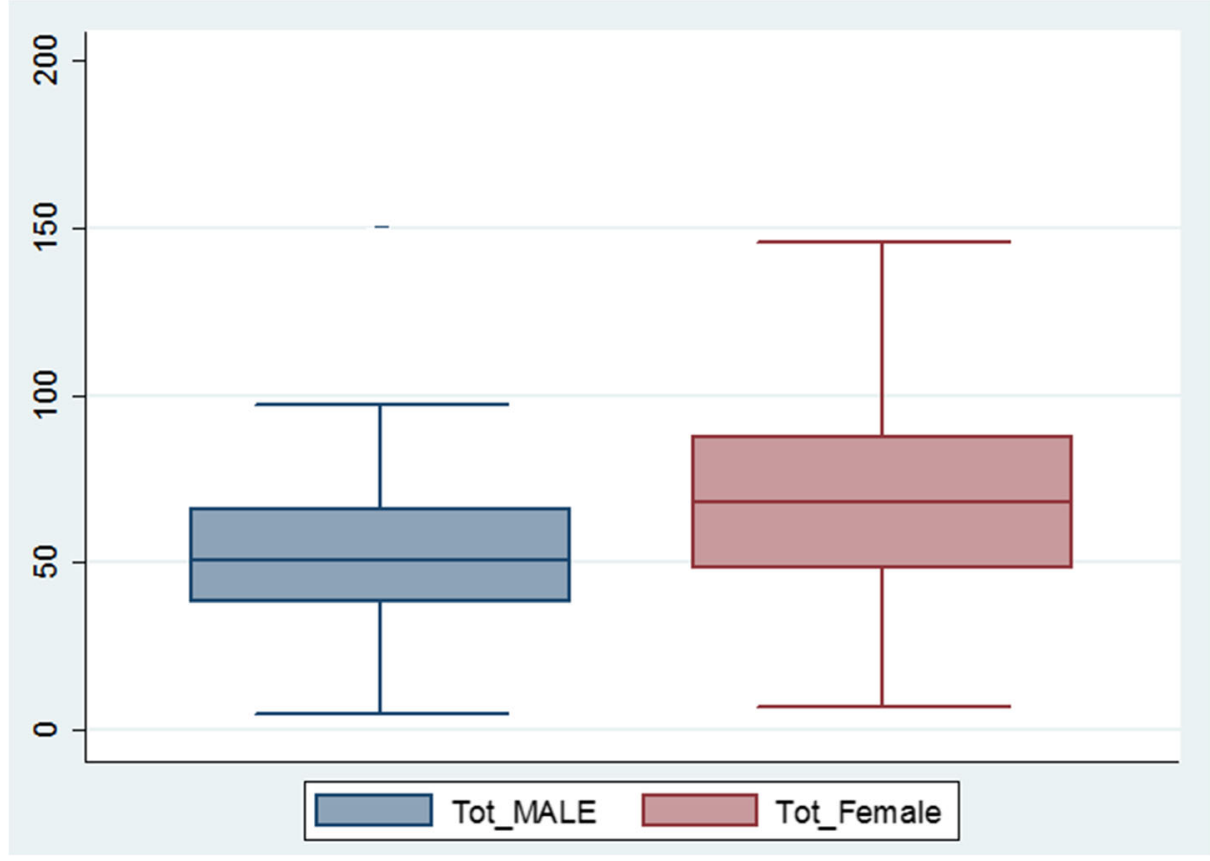

Fig. 4 Total labor days contribution by men and women 
Table 3 Men and women participation in different agricultural activities (days/ha)

\begin{tabular}{|c|c|c|c|c|c|c|c|c|c|}
\hline & $\begin{array}{l}\text { Male } \\
\text { labor }\end{array}$ & $\begin{array}{l}\text { Female } \\
\text { labor }\end{array}$ & $\begin{array}{l}\text { Mean } t \\
\text { test }\end{array}$ & $\begin{array}{l}\text { Male } \\
\text { labor }\end{array}$ & $\begin{array}{l}\text { Female } \\
\text { labor }\end{array}$ & $\begin{array}{l}\text { Mean } t \\
\text { test }\end{array}$ & $\begin{array}{l}\text { Male } \\
\text { labor }\end{array}$ & $\begin{array}{l}\text { Female } \\
\text { labor }\end{array}$ & $\begin{array}{l}\text { Mean } t \\
\text { test }\end{array}$ \\
\hline Nursery preparation & 5.57 & 2.95 & $7.02 * * *$ & - & - & - & - & - & - \\
\hline Transplanting & 0 & 22.95 & $19.91 * * *$ & - & - & - & - & - & - \\
\hline Seeding & - & - & - & 4.58 & 1.23 & $9.43 * * *$ & 4.69 & 3.35 & $2.01 *$ \\
\hline Weeding & 0.27 & 4.78 & $32.56 * * *$ & 1.00 & 1.21 & 1.9 & 11.71 & 16.07 & $3.01 * *$ \\
\hline Irrigation application & 0.73 & 3.10 & $9.44 * * *$ & 1.17 & 0.12 & $11.38^{* * * *}$ & 0.37 & 0.19 & 1.3 \\
\hline Fertilizer application & 18.25 & 6.08 & $17.80 * * *$ & 1.75 & 0.31 & $12.04 * * *$ & 1.23 & 0.47 & $4.11 * * *$ \\
\hline
\end{tabular}

\subsection{Determinants of women's participation in agriculture}

Table 4 highlights the role of socioeconomic variables in determining women's participation in agriculture. Women in large landholding and non-agricultural income households contribute less to agricultural activities due to their access to off-farm economic activities and ability to hire labor. On the other hand, increasing family size, agriculture as a main occupation of the household head, and woman household head all act as contributing factors for increased women's participation in agricultural activities over that of men. Large family size is generally related to poor income level and more females in the household (Maharjan and Khatri-Chettri 2006). Understanding these results can play an important role in better targeting of CSA intervention for women farmers.

\subsection{Women and CSA technologies}

Farmers in the household survey and focus discussions provided a list of agriculture and related activities where women's involvement is high and highlighted key CSA interventions suitable in each activity along with their expected impacts on labor, income, and yield (Table 5). The roles of these CSA technologies in improving crop yield and farm income while reducing women's labor burden in agriculture are also well recognized as per literature (Kristjanson et al. 2017; Jost et al. 2016).

Table 4 Household characteristics and women's involvement in agriculture

\begin{tabular}{lrr}
\hline $\begin{array}{l}\text { Dependent variable: Total labor contribution by women in different agricultural } \\
\text { activities }\end{array}$ & $\begin{array}{l}\text { Coefficient } \\
\text { (SE) }\end{array}$ & $t$ value \\
\hline Landholding size (hectare) & $-6.47(2.94)$ & $-2.20^{* *}$ \\
Family size (number) & $1.89(0.86)$ & $2.19^{* *}$ \\
Main occupation of household head (1, agriculture; 0, otherwise) & $8.79(3.81)$ & $2.31^{* *}$ \\
Gender of household head (1, women; 0, otherwise) & $1.05(5.84)$ & 0.18 \\
Non-agriculture income (\%) & $-0.18(0.08)$ & $-2.36^{* * *}$ \\
Constant & $62.73(4.77)$ & $13.12^{* *}$ \\
Number of observation & 215 & \\
$R^{2}$ & 0.10 & \\
$F(5,209)$ & 4.2 & 0.001 \\
Prob $>F$ & & \\
\hline
\end{tabular}

$* *$ and $* * *$ indicate significance at $5 \%$ and $1 \%$, respectively 
Table 5 List of women-led agricultural activities and CSA interventions

\begin{tabular}{|c|c|c|}
\hline Key activities & Key climate-smart interventions & Expected impact on labor/yield/income \\
\hline Weeding & - Weed management activities & - Reduction in labor hours \\
\hline $\begin{array}{l}\text { Collection of fodder or } \\
\text { fuelwood }\end{array}$ & - Agroforestry & $\begin{array}{l}\text { - Reduction in fuelwood } \\
\text { collection time }\end{array}$ \\
\hline $\begin{array}{l}\text { Collection of water for } \\
\text { domestic or irrigation } \\
\text { purpose }\end{array}$ & $\begin{array}{l}\text { - Management of water harvesting } \\
\text { structures } \\
\text { - Management of irrigation through solar } \\
\text { pumps }\end{array}$ & $\begin{array}{l}\text { - Reduction in water collection } \\
\text { time }\end{array}$ \\
\hline $\begin{array}{l}\text { Horticultural activities } \\
\text { (vegetable cultivation } \\
\text { and high-value fruit) }\end{array}$ & $\begin{array}{l}\text { - Water-smart technologies such as } \\
\text { drip irrigation, especially for } \\
\text { drought-prone areas } \\
\text { - Improved home gardens }\end{array}$ & $\begin{array}{l}\text { - Reduction in time and labor } \\
\text { for irrigation, additional source } \\
\text { of income (leading to improved } \\
\text { food security) }\end{array}$ \\
\hline Sowing & $\begin{array}{l}\text { - Improved high-yielding variety of seeds } \\
\text { - Direct seeded rice, zero-tillage wheat }\end{array}$ & - Improved yield and income \\
\hline $\begin{array}{l}\text { Livestock management } \\
\text { (fodder collection and } \\
\text { milking) }\end{array}$ & $\begin{array}{l}\text { - Fodder cultivation and management } \\
\text { (fodder bank, improved varieties, } \\
\text { silage/hey preparation) } \\
\text { - Weather-friendly housing for livestock } \\
\text { - Connect with local dairy } \\
\text { - Livestock manure management }\end{array}$ & $\begin{array}{l}\text { - Improve milk production during } \\
\text { weather stress conditions } \\
\text { - Better livestock management } \\
\text { leading to secured income } \\
\text { especially in cases of crop loss, } \\
\text { reduced labor for livestock- } \\
\text { related activities } \\
\text { - Increase nutrient supply for crop } \\
\text { cultivation }\end{array}$ \\
\hline $\begin{array}{l}\text { Weather information, } \\
\text { agro-advisory, and } \\
\text { market information }\end{array}$ & $\begin{array}{l}\text { - Agro-advisory and market information } \\
\text { customized for women }\end{array}$ & $\begin{array}{l}\text { - Access to information for better } \\
\text { management of activities, } \\
\text { especially useful for females } \\
\text { responsible for all agricultural } \\
\text { operations including marketing } \\
\text { of produce }\end{array}$ \\
\hline Post-harvest & $\begin{array}{l}\text { - Improved post-harvesting practices such } \\
\text { as improved storage and processing } \\
\text { methods }\end{array}$ & $\begin{array}{l}\text { Reduces labor as well as food/crop } \\
\text { losses during post-harvest opera- } \\
\text { tions }\end{array}$ \\
\hline Value addition & $\begin{array}{l}\text { - Capacity building on value addition in } \\
\text { agricultural products before marketing }\end{array}$ & $\begin{array}{l}\text { - Increase value of agricultural } \\
\text { produce }\end{array}$ \\
\hline Domestic energy & - Biogas & $\begin{array}{l}\text { - Meeting energy requirements at } \\
\text { lower costs }\end{array}$ \\
\hline Capacity building & $\begin{array}{l}\text { - Capacity building on application and } \\
\text { implementation of weather resilient } \\
\text { technologies and services }\end{array}$ & $\begin{array}{l}\text { - Better and timely use of weather- } \\
\text { resilient technologies } \\
\text { - Socioeconomic empowerment of } \\
\text { women farmers by strengthening } \\
\text { their knowledge and skills }\end{array}$ \\
\hline
\end{tabular}

\subsection{Impact of technologies on CSA indicators}

Evaluation of some of these CSA interventions highlighted that all selected technologies have significant potential to reduce women's labor contribution in agricultural activities, particularly in transplanting, nutrient management, and sowing of crops (Fig. 5). Direct seeded rice (zero tillage and low tillage using machine) and green manuring (GM) in particular can significantly reduce women's labor hours/days in agriculture.

Figure 6 presents impact of technologies on efficiency, equity, gender, environment, and sustainability indicators of CSA. Higher production efficiency over farmers' practices was observed in DSR methods, LLL, and SRI technologies. This was mainly due to a positive effect of technology in crop productivity. Similarly, for the equity indicator, employment 


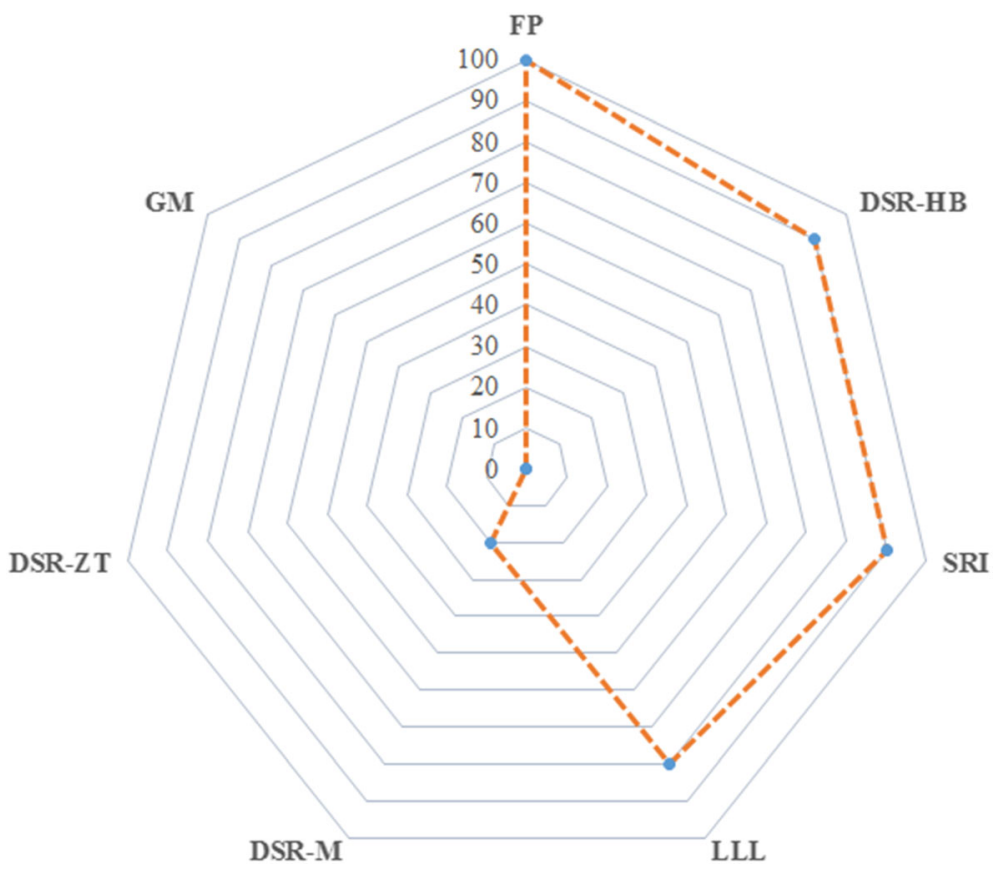

Fig. 5 Level of women's labor contribution reduction under different CSA technologies compared to baseline (i.e., FP)

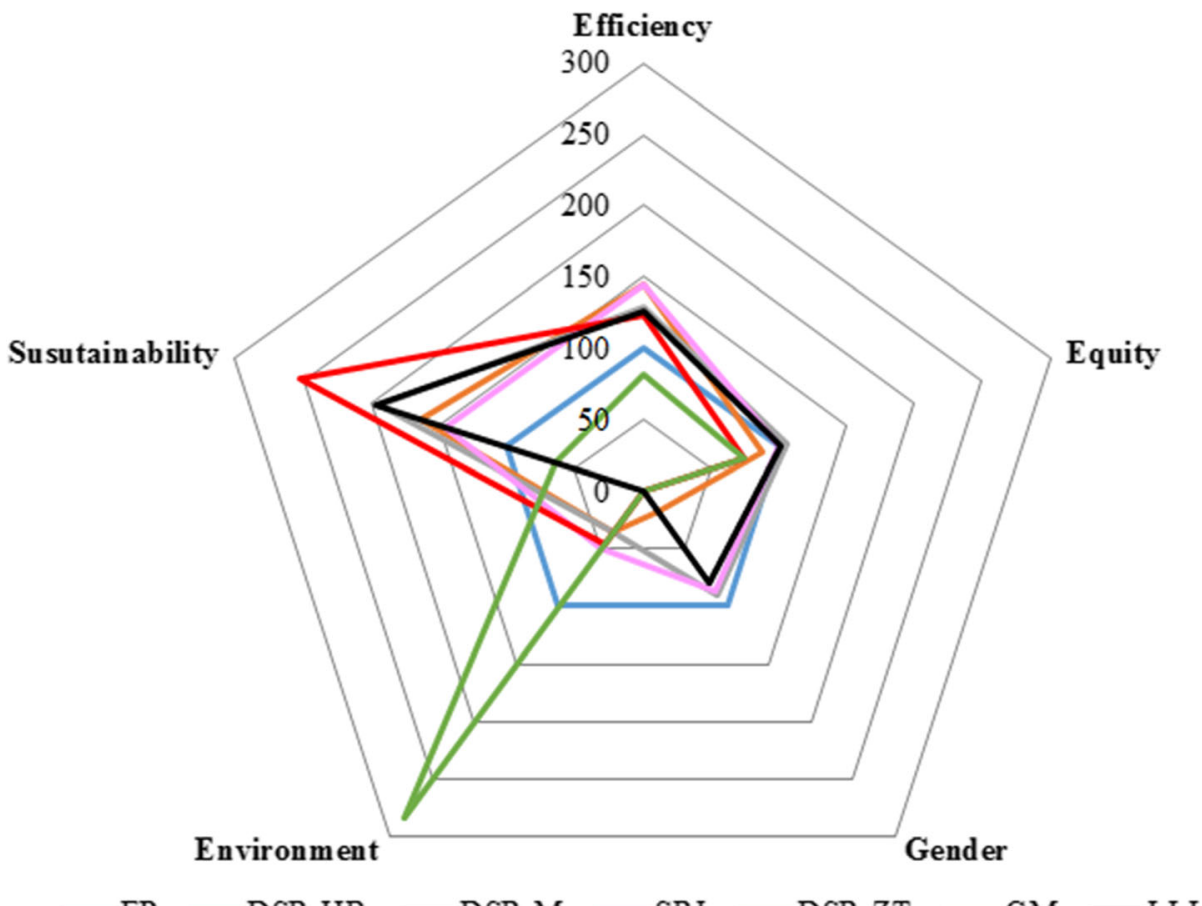

FP DSR-HB DSR-M

Fig. 6 Impact of CSA technologies on five indicators 
generation and higher calorie production were observed for DSR machine (after plowing), SRI, and LLL.

In zero-till DSR and GM, no women's participation was observed whereas a higher proportion of participation of women was observed in farmers' conventional practice (without CSA technology interventions). Sustainability index was found to be higher in zero-till DSR, indicating higher sustainability than other farming technologies. The environmental index was found to be higher for GM applied in rice fields indicating a higher potential of greenhouse gas emission compared to other technologies. Lowest emission values were calculated for DSR using machine and DSR hand broadcasting, which is much lower than the GHG emission index of GM rice and farmers' practice (FP).

\section{Conclusions}

The study adopts a top-down approach of examining the potential of CSA to reduce women's labor burden in agriculture in the wake of climate change. A targeted approach using the hotspot methodology can prove to be useful in cases where prioritization of resources is a criterion. This method of hotspot identification and targeting of CSA options is seldom being used by most of the current development-related programs on women and agriculture. National and sub-national government and development organizations also focus on implementation of outcome-oriented strategies which tend to cover a large proportion of the target population, without much streamlining. This study promotes a more focused approach to identify more vulnerable regions (hotspots) related to women in agriculture-poverty-climate risk and promote technologies for reducing labor burdens for women in those regions.

Based on the activities majorly conducted by women, this study shows that CSA technologies and practices such as direct seeded rice, zero tillage machines, laser land leveling, and green manuring can reduce women's labor burden in agriculture. Other CSA technologies such as crop harvesters, weeder, solar pump irrigation, and post-harvest management practices can also substantially reduce women's labor burden. However, apart from reduction in labor hours, CSA also has an instrumental role in improving women's access to agricultural resources and decision-making process as well as provide linkages to new market opportunities. Further studies, therefore, are needed to consider holistic approaches that would evaluate the implications of different CSA interventions on men and women in different socioeconomic settings and roles.

Acknowledgments This work was implemented as part of the CGIAR Research Program on Climate Change, Agriculture and Food Security (CCAFS), which is carried out with support from the CGIAR Trust Fund and through bilateral funding agreements. For details, please visit https://ccafs.cgiar.org/donors.

Disclaimer The views expressed in this document cannot be taken to reflect the official opinions of these organizations.

\section{Annexure 1}

For each technology and indicators (except environment), primary data were used for calculation of different index.

Efficiency: Proxy indicators such as crop yields, benefit-cost ratio, and unit cost of production were taken for calculation. For each intervention, production efficiency was calculated and output compared with farmers' practice. 
Equity: Total number of man-days required for each technology was calculated and compared with farmers' practice. Similarly, additional calories produced from each intervention were calculated and compared. Averages of these two indexes are used for calculating equity index for each technological intervention.

Gender: Female participation in each technological intervention was used and compared with farmers' practice for gender index.

Environment: To calculate the environment index, secondary source of GHG emission for upper Indo-Gangetic Plain from "Pathak H. and Aggarwal P.K., (Eds.) (2012) Low carbon technologies for Agriculture: A study report on Rice and Wheat system in the Indo-Gangetic plains. IARI" was used. During calculation, GHG emissions from burning of rice straw were discarded. Similarly, $\mathrm{CO}_{2}$ emissions from on-farm and off-farm were also not included as we are not producing fertilizers and biocides for rice production. To convert all units into $\mathrm{CO}_{2}$ equivalent, $\mathrm{H}_{4}$ and $\mathrm{N}_{2} \mathrm{O}-\mathrm{N}$ were multiplied by 23 and 310 (Wightman, J. Production and Mitigation of Greenhouse Gases in Agriculture) respectively.

Sustainability: For sustainability, proxy indicators nitrogen use efficiency and energy use efficiency (diesel used) were used for calculation and result compared with farmers' practice. Average of both nitrogen use efficiency and energy use efficiency was taken as sustainability index.

Index development: The proxy indicators under each intervention were used for comparing with the farmers' preference (baseline data) for index development. Index development was done by using the formula:

$$
\text { Index }=((\text { Data with improved practice }) /(\text { Data with farmers practice })) \times 100
$$

The overall index development for each indicator under each intervention was calculated as follows:

Example:

$$
\text { Index }=(\text { Employment index }+ \text { Additional calories produced index } / 2) \times 100
$$

Except for Environmental index for GHGs, the formula is reversed as in (GHG value from farmers' practice/value from intervention) $\times 100$.

Open Access This article is distributed under the terms of the Creative Commons Attribution 4.0 International License (http://creativecommons.org/licenses/by/4.0/), which permits unrestricted use, distribution, and reproduction in any medium, provided you give appropriate credit to the original author(s) and the source, provide a link to the Creative Commons license, and indicate if changes were made.

Publisher's Note Springer Nature remains neutral with regard to jurisdictional claims in published maps and institutional affiliations.

\section{References}

Agarwal B (2013) Food security, productivity, and gender inequality. The Oxford Handbook of Food, Politics, and Society. https://doi.org/10.1093/oxfordhb/9780195397772.013.002

Aly HY, Shields MP (2010) Gender and agricultural productivity in a surplus labour, traditional economy: empirical evidence from Nepal. J Dev Areas 43(2):111-124

Bradshaw S, Linneker B (2017) The Gendered Terrain of Disaster Risk Reduction Including Climate Change Adaptation, in Kelman I, Merecer J, Gaillard JC (eds) Handbook of Disaster Risk Reduction Including Climate Change Adaptation. Routledge, London, UK 
CBS (2013a) National Sample Census of agriculture Nepal 2011/2012: national report. Central Bureau of Statistics, Kathmandu

CBS (2013b) Small area estimation of poverty. Central Bureau of Statistics, Government of Nepal, Thapathali

Chaudhury M, Kristjanson P, Kyagazze F, Naab JB, Neelormi S (2012) Participatory gender-sensitive approaches for addressing key climate change related research issues: evidence from Bangladesh, Ghana, and Uganda. Working Paper 19. Copenhagen: CGIAR Research Program on Climate Change, Agriculture and Food Security (CCAFS)

Edmunds D, Sasser J, Wollenberg E (2013) A gender strategy for pro-poor climate change mitigation. CCAFS Working Paper no. 36. CGIAR Research Program on Climate Change, Agriculture and Food Security (CCAFS). Copenhagen, Denmark. Available online at: www.ccafs.cgiar.org. Accessed 15 Aug 2017

FAO (2010a) Gender dimensions of agricultural and rural employment: differentiated pathways out of poverty. The Food and Agricultural Organization of the United Nations, Rome

FAO (2010b) Climate smart agriculture: policies, practices and financing for food security, adaptation, and mitigation. Food and Agriculture Organization (FAO) of the United Nations, Rome, Italy

FAO (2011) State of food and agriculture: women in agriculture, closing the gender gap for development. Food and Agriculture Organization of the United Nations, Rome

Gartaula HN, Niehof N, Leontine V (2010) Feminization of agriculture as an effect of male outmigration: unexpected outcomes from Jhapa District, Eastern Nepal. Int J Interdisciplinary Soc Sci 5(2):565-577

Goh A (2012) A literature review of the gender-differentiated impacts of climate change on women's and men's assets and well-being in developing countries (CAPRi Working Paper No. 106). Washington, DC: CGIAR System Wide Program on Collective Action and Property Rights (CAPRi)

Goldsmith R, Feygina I, Jost JT (2013) The gender gap in environmental attitudes: a system justification perspective. In: Alston M, Whittenbury K (eds) Research, action and policy: addressing the gendered impacts of climate change. Springer, Amsterdam

GoN (2010) National Adaptation Programme of Action (NAPA) to climate change. Ministry of Environment, Government of Nepal, Singhdarbar

GoN (2014) Labour migration for employment: a status report for Nepal. Ministry of Labour and Employment, Government of Nepal, Singhdarbar

Howden SM, Soussana JF, Tubiello FN, Chhetri N, Dunlop M, Meinke H (2007) Adapting agriculture to climate change. Proc Natl Acad Sci 104(50):19691-19696

Huyer S (2016) Closing the gender gap in agriculture. Gend Technol Dev 20(2):105-116. https://doi.org/10.1177 /097185241664387

Huyer S, Twyman J, Koningstein M, Ashby J, Vermeulen S (2015) Supporting women farmers in a changing climate: five policy lessons. CCAFS Policy Brief no. 10. Copenhagen, Denmark: CGIAR Research Program on Climate Change, Agriculture and Food Security (CCAFS). Available online at: www.ccafs.cgiar.org. Accessed 15 Aug 2017

Jost C, Kyazze F, Naab J, Neerlormi S, Kinyangi J, Zougmore R, Aggarwal P, Bhatta G, Chaudhury M, TapioBistrom ML, Nelson S, Kristjanson P (2016) Understanding gender dimensions of agriculture and climate change in smallholder farming communities. Climate and Development 8 (2):133-144

Khatri-Chhetri A, Aggarwal PK, Joshi PK, Vyas S (2017) Farmers' prioritization of climate-smart agriculture (CSA) technologies. Agric Syst. https://doi.org/10.1016/j.agsy.2016.10.005

Krishnamurthy PK, Hobbs C, Matthiasen A, Hollema SR, Choularton RJ, Pahari K, Kawabata M (2013) Climate risk and food security in Nepal-analysis of climate impacts on food security and livelihoods. CCAFS Working Paper no. 48. CGIAR Research Program on Climate Change, Agriculture and Food Security (CCAFS), Copenhagen, Denmark. Available online at: www.ccafs.cgiar.org. Accessed 5 July 2017

Kristjanson P, Bryan E, Bernier Q, Twyman J, Meinzen-Dick R, Kieran C, Ringler R, Jost C, Doss C (2017) Addressing gender in agricultural research for development in the face of a changing climate: where are we and where should we be going? Int J Agric Sustain 15(5):482-500. https://doi.org/10.1080 $/ 14735903.2017 .1336411$

MacGregor S (2010) A stranger silence still: the need for feminist social research on climate change, Sociological Review, 57, Issue Supplement S2, Special Issue: Sociological Review Monograph Series: Nature, Society and Environmental Crisis, Carter B, Charles N (eds) p124-140

Maharjan KL, Khatri-Chettri A (2006) Household food security in rural areas of Nepal: relationship between socio-economic characteristics and food security status, International Association of Agricultural Economists, Issues 25624, Available online at: https://ideas.repec.org/p/ags/iaae06/25624.html. Accessed 5 July 2017

MoAD (2015) Statistical information on Nepalese agriculture 2014/15. Government of Nepal, Ministry of Agricultural Development, Statistics Section, Kathmandu

MoLE (2015) Labour migration for employment a status report for Nepal: 2014/2015. Government of Nepal, Ministry of Labour and Employment, Kathmandu 
Morton JF (2007) The impact of climate change on smallholder and subsistence agriculture. PNAS 104(50): $19680-19685$

Nellemann C, Verma R, Hislop L (2011) Women at the frontline of climate change: gender risks and hopes: a rapid response assessment. United Nations Environment Program, GRID, Arendal

Nelson S, Huyer S (2016) A gender-responsive approach to climate-smart agriculture: evidence and guidance for practitioners. FAO and CCAFS. Available at http://www.fao.org/3/a-be879e.pdf. Accessed 15 Aug 2017

NEOC (2015) Disaster database for Nepal. Ministry of Home Affairs, National Emergency Operation Center, Available at: http://neoc.gov.np/en/download/Disaster-Data/7/. Accessed 6 July 2017

Nightingale AJ (2011) Bounding difference: intersectionality and the material production of gender, caste, class and environment in Nepal. Geoforum 42(2):153-162

Pathak H, Aggarwal PK (2012) Low Carbon Technologies for Agriculture: A Study on Rice and Wheat Systems in the Indo-Gangetic Plains. Indian Agricultural Research Institute (IARI). New Delhi, India

Peterman A, Behrman JA, Quisumbing AR (2014) A review of empirical evidence on gender differences in nonland agricultural inputs, technology and services in developing countries. In Quisumbing et al. edts. Gender in agriculture: closing the knowledge gap, pp 145-186

Quisumbing AR, Meinzen-Dick R, Raney TL, Croppenstedt A, Behrman JA, Peterman A (2014) Gender in agriculture: closing the knowledge gap. Springer. Croppenstedt, A., M. Goldstein and N. Rosas. 2013. Gender and Agriculture: Inefficiencies, Segregation and Low Productivity Traps

Steenwerth KL, Hodson AK, Bloom et al A J (2014) Climate-smart agriculture global research agenda: scientific basis for action. Agri \& Food Sec 3(11)

Tamang S, Paudel KP, Shrestha KK (2014) Feminization of agriculture and its implications for food security in rural Nepal. J Forest \& Livelihood 12(1): 20-32

UNDP (2013) Overview of linkages between gender and climate change. United Nations Development Programme, New York

UNDP (2016) Human development report 2016: human development for everyone. The United Nations Development Program, New York

Vermeulen SJ, Campbell BM, Ingram JSI (2012) Climate change and food systems. Ann Rev Environ Resour $37: 195-222$ 